UNRAM Law Review is licensed under a Creative Commons Attribution 4.0 International License, which permits unrestricted use, distribution, and reproduction in any medium, provided the original work is properly cited. p-ISSN: 2548-9267 | e-ISSN : 2549-2365, Open Access at : http://unramlawreview.unram.ac.id/index.php/ulr

\begin{tabular}{c|c|c|c|c|}
\hline Volume & Issue & Page & April & p-ISSN: 2548-9267 \\
3 & 1 & $35-43$ & 2019 & e-ISSN : 2549-2365
\end{tabular}

\title{
The Authority Of Property And Heritage Agency Regarding Making Of Inheritance Certificate For The Descendant Of East Asian
}

\author{
Nova WinantikaRindangKirana \\ Program Studi Magister Kenotariatan \\ Pasca Sarjana Fakultas Hukum Universitas Brawijaya \\ Jl. MT. Haryono No. 169, Malang 65145, Indonesia \\ Email: kirananovayop@gmail.com \\ I NyomanNurjaya \\ Program Studi Magister Kenotariatan \\ Pasca Sarjana Fakultas Hukum Universitas Brawijaya \\ Jl. MT. Haryono No. 169, Malang 65145, Indonesia \\ Email: kirananovayop@gmail.com \\ Herman Suryokumoro \\ Program Studi Magister Kenotariatan \\ Pasca Sarjana Fakultas Hukum Universitas Brawijaya \\ Jl. MT. Haryono No. 169, Malang 65145, Indonesia \\ Email: kirananovayop@gmail.com
}

\begin{abstract}
This study aims to know and analyse which norms are enacted in the making of inheritance certificate and to know the strength of law in the certificate of inheritance made by Property and Heritage Agency after the enactment of Law No. 23 of 2006 on Population Administration. The research method used by the writer is statute approach and conceptual approach. The basis of the authority of Property and Heritage Agency is not in accordance with the state of the nation at this time and also based on the hierarchy of legislation is lower than the position of Law No. 23 of 2006. In addition, the certificate of inheritance made by the Property and Heritage Agency does not guarantee certainty and legal protection for Indonesian citizens because the strength of proof is not as perfect as the deed of inheritance made by the Notary.
\end{abstract}

Key words: Authority, Certificate of Inheritance, Foreign Eastern decendants.

\section{INTRODUCTION}

It is been knowing that Indonesia is a state which lived not only by particular ethnic, even before the colonialism (Portuguese and dutch), the population had not been segmented according to their race, culture or class, so that why Indonesia can be concluded as a compound state. ${ }^{1}$

The inheritance law in Indonesia is divers which is pluralism, that because the unification has not made yet on its inheritance law. The inheritance las is a law which contains the regulation \footnotetext{
p.30.

${ }^{1}$ Habib Adjie. (2005). “Stop! Diskriminasi Dalam Pembuatan Bukti Ahli Waris” Renvoi. No. 24 Tahun Kedua. Jakarta.
} 
concerning process to forward and transfer of tangible and intangible property from a human to its decent. ${ }^{2}$

Legal event of someone's death delivered to a legal consequences which is an issues on the rights and obligations matter. The obligations of the decease people regulated under the inheritance law. The management of inheritance has a strong link with certificate of inheritance rights. The inheritance rights certificate is a part of inheritance law which divided into several types under Indonesian law, which are: customary inheritance law, western inheritance law and Islamic inheritance law.

The certificate of inheritance rights is a letter which made by/in front of the official authority where its content explaining on who is the heir that has the rights to inherited the inheritance from someone who has passed away or is called as a heir. The certificate of inheritance rights is one of the evidence to dividing the inheritance. The position of certificate of inheritance rights on inheritance is very important, basically when the inheritance is switched its rights to the other subject (buyer/ other heirs) is need an explanation on who is really had the rights of the inheritance, such as land or house.

The making of certificate of inheritance rights is distinguished on the authority of who has the rights to make it in accordance with the population classification in Indonesia at the time of dutch colonialism which based on the supreme court circular letter of Republic of Indonesia on may 8, 1991 Number MA/kumdil/171/V/K/1991 refer to directorate of land registration of domestic department of director general of agrarian affairs on December 20. 1969 Number Dpt/12/63/12/69 concerning the certificate of inheritance and proof of citizenship that have been recognized since before the independence then the certificate of inheritance for the Indonesian citizen should be:

1. The group of European Descent made by a notary

2. The group of native citizen or is called "Pribumi", the certificate is made by the heir and witnessed by the headman/ village head and known by the sub ditstrict

3. The group of Chinese made by a notary

4. The group of foreign east not Chinese made by the heritage hall.

The classification categories as the form of previous regulation which listed under article 131 of IS (IndischeStaatsregeling).

For the importance on transfer of the heir name of a land on the decision of who has the rights to inherit the inheritance then it will be needed a letter which stated a proof that the person truly having the rights. The intended letter of evidence consists of:

Untukkepentinganpendaftaranbaliknamawarisatastanahdalamhalpenentuansiapasaja yang benar-benarberhakmewarisihartapeninggalanpewarismakadibutuhkansurat yang menyatakanbuktibahwaseseorangtersebutmemangbenar-benar yang berhak. Suratbukti yang dimaksudterdiridari : ${ }^{3}$

1. Will of the heir, or

2. Court decision, or

3. Judge decision/court head, or

4. The certificate of inheritance

The provision on making a certificate of inheritance based on the Indonesian citizen classification since the ducth colonialism which causes the differences on form of the certificate of inheritance and the official wihich have the authority to make it. The existence of the

\footnotetext{
${ }^{2}$ Soepomo.(1996). Bab-bab Tentang Hukum Adat. Jakarta: Penerbitan Universitas, p.72.

${ }^{3}$ Peraturan Menteri Negara Agraria Nomor 3 Tahun 1997 Pasal 111 ayat 1c
} 
procedures on making the inheritance certificate caused by at least there are three institution which recognized its authority by the law to make the inheritance document, which are : ${ }^{4}$

a. For the Indonesian citizen, native citizen, the certificate of inheritance which made by the the heir and witnessed by two witnesses also strengthened by the headman and sub district head at the residence of the heir at the time of death.

b. For the Indonesian citizen which grouped on Chinese descent, his certificate of inheritance is made in front of the notary.

c. For the Indonesian citizen who is east foreign descent, his certificate of inheritance is made in the heritage hall.

The differences on making the certificate of inheritance according to the classifications on the Dutch colonialism surely caused law inequality and the rights as Indonesian citizen which should be getting certainty and same law protection. The government effort to create law equality and the rights of Indonesian citizen which formed on the formation of law number 12 year 2006 concerning citizenship and law number 23 year 2006 concerning citizen administration as updated with law number 24 year 2013 concerning citizen administration. The purpose of establishment of the law is to eliminate the discrimination on the citizen administration to create equality before the law and the rights as Indonesian citizen.

Therefore, The basic authority of the heritage hall related concerning the making of the certificate of inheritance rights is needs to be question on the application of law number 23 year 2006 concerning citizen administration which stated revocation of administration regulation according to the classification of groups therefore there are no more the grouping of Indonesia citizen. therefore the rights of Indonesian citizen on getting law certainty must be the same.

The certificate of inheritance rights is a proof of someone to get his rights as the heir. As a proof tool, the certificate of inheritance rights is hoped to provide guarantee on law certainty for the owner. The inheritance certificate which issued by the heritage hall is not a problem as long as there is no dispute which caused a lawsuit from other party, whereas the pluralistic on inheritance law concerning grouping of the citizen in the past causes the regulation on form, law status and who has the rights to make the certificate of inheritance rights still not adequately regulated and still diverse. On its authority the heritage hall making the inheritance certificate for foreign eastern descendant in the form of letters, while a notary has an authority to make inheritance statement for Chinese group on the form of inheritance statement deed. The differences on the form of inheritance certificate which arises a problem because the strength of its proof is not the same in which the deed more perfect on its proof compared to a letter while the application of law number 23 year 2006 is appropriate for the whole Indonesian citizen to get the same rights and law concerning the protection and certainty of law.

According to the background of study which stated by the writer there it arises a problem, in which norm that applicable on making the certificate of inheritance rights in connection with the enactment of the law number 23 year 2006? And how is the legal force at the certificate of inheritance which made by the heritage hall after the enactment of law number 23 year 2006?

\section{METHOD}

The methodology on this journal is normative juridical which are by examining the articles, principles and doctrines that often used by the legal expert concerning the problem research which is the authority of heritage hall on the making of certificate of inheritance rights for the descent of foreign east since the enactment of law number 23 year 2006 concerning the citizen administration. This research is about the norms which bases the authority of heritage hall

${ }^{4}$ Budi Harsono.(2005) Peraturan Menteri Negara Agraria/Kepala Badan Pertanahan Nasional Nomor 3 Tahun 1997, Hukum Agraria Indonesia (Himpunan Peraturan Hukum Tanah), Edisi Revisi.Jakarta: Djambatan.Pasal 111. 
on making the certificate of inheritance. Aside from that, the legal strength of the inheritance certificate which made by the heritage hall.

The approach concept which uses on this rsearch is a legal approach (statute approach) and conceptual approach. This method used in purpose to acknowledge which norm that applicable to make the certificate of inheritance rights after the enactment of law number 23 year 2006. By virtue of the legal principles so that it could find the answer which norm more appropriate to be applicable on making the inheritance certificate since the law number 23 year 2006 applied as well as to acknowledge the legal strength of inheritance certificate which made by the heritage hall after enactment of law number 23 year 2006.

\section{DISCUSSION}

\section{The NORM which govern of the making the certificate of inheritance before the establish- ment of law number 23 year 2006}

The existence of inheritance rights has been around since the colonialism. Therefore there are various regulation which underlie the making of inheritance certificate along with the history of Indonesian citizen.

First is the regulation which listed on the supreme court letter of Republic of Indonesia May 81991 Number. MA/kumdil/171/V/K/1991 which appointed on the Directorate of land registration directorate General of agrarian affairs December 201969 number Dpt/12/63/12/69 which stated that in purpose of uniformity also based on the citizen classification that has ever existed since before the independence then the certificate of inheritance rights which applicable for Indonesian citizen are:

a. European descent group made by a notary

b. The indigenous group (native Indonesian population) made by the heirs and witnesses by the head village and sub district head

c. The chinese descendants group made by a notary

d. The foreign eastern descendants group are made by the heritage hall

Moreover, the regulation on the certificate of inheritance for the importance of registration interest behind the name of the inheritance of the land which based on the article 111 section 1 letter $\mathrm{c}$ regulation of the agrarian minister/ head of the land affairs number 3 year 1997 which stated the proof letter as a heir may be form on:

a. testament from the heir

b. Court decision

c. Judge/court head statement

d. -For the native Indonesian citizen: an inheritance letter that made by the heir and witnessed by two witnesses and strengthened by the head village and sub district head.

- For Indonesian citizens of Chinese descent the certificate of inheritance rights is made by a notary

- For Indonesian citizen of foreign east descent the certificate finheritance rights made by a heritage hall.

The regulation of the agrarian minister rolled as an implementing regulation from the government regulation number 24 year 1997 concerning the land registration. According to article 42 regulated on the transfer of rights since an inheritance on the article 42 section 1 stated that ; in terms of registration on the transfer of rights because of a land inheritance which have already registered and the right of ownership on an apartment unit as required by virtue of article 36, it is a mandatory to be submitted by the one who receive the rights of a land or an ownership rights of an apartment unit as an inheritance to the land office, the certificate on 
rights of the party, a death certificate of someone who recorded as a right holders and a proof letter as a heir"

The regulation concerning inheritance further regulated under gazette year 1916 number 517 which explains that "concerning an instruction from heritage hall that it is need a certificate of inheritance from the heritage hall particularly for the foreign east citizen for the importance on the process of transfer a title of the inheritors. Other than that it also used to be enroll and open the testament.

By pointing on the gazette, the supreme court of Indonesia at may 81991 , as well as according to article 111 section 1 letter $C$ section 4 of the regulation of agrarian minister/head of the national land agency number 3 year 1997, and gazette year 1916 number 517 stated that the heritage hall has the authority to make certificate of inheritance for the east foreign group, this regulation work as a basis of the heritage hall to exercise its authority.

\section{The Norms that regulate the elimination citizen classification}

The national mid term development plan year 2004 to 2009, one of the development purpose particularly on the field of law is to eliminate all of the discrimination in any form, which have done by improving, changing or negation of the things which have been existed on the previous law which has not been needed and not in accordance with the new legal system. ${ }^{5}$

Accordingly, the government establish a regulation in purpose to eliminate the citizen classification and all the form of discrimination and class. It begins from the application of the law number 12 year 2006 concerning citizenship which furthermore penetrate to the administration of citizen management which is the act number 24 year 2013 as the amendment of the act number 23 year 2006 concerning the citizen administration, as well as the act number 40 year 2008 concerning the elimination of ethnic and class discrimination.

The analysis of contradiction on circular letter of the supreme court of republic Indonesia may 8 1991, the regulation of agrarian minster number 3 year 1997 with law number 23 year 2006 concerning the administration of citizen by virtue of the principles and legal theory

The formation of the law is need to be guided to the good principles of law. Satjipto Raharjo on his book stated that :

"The law principles is a heart of legal regulation. Because the law principles is the most extensive basic for the born of a law regulation. This means that those law regulation in the end may be returned to the principles. Except if its called a basic, the law principles is reasonable to be called as a reason for the establishment of a law regulation, or as a ratio legis from the regulation. The legal principles will never be out of strength by implementing a law regulation, however will be stay exist and delivers further regulations ". ${ }^{6}$

The existence of the legal principles, a law is not merely a collection of rules, therefore it is caused by those principles contains value and ethical demands. ${ }^{7}$

The form of a legislation required on the formation principles of a good and ideal regulation, the purpose is so that it does not to make mistake and defect in the formation of the norms. The law number 12 year 29011 concerning the the formation of a legislation remains to the legislator to pay attention to the principles of a good legislation and its content material principle. The good principles of the legislation according to Maria Farida, including: ${ }^{8}$

\footnotetext{
${ }^{5}$ Herlien Budiono.(2006). Asas Keseimbangan Bagi Hukum Perjanjian Indonesia, Hukum Perjanjian Berlandaskan Asas-AsasWigati Indonesia.Bandung: Citra Aditya Bakti, p. 84.

${ }^{6}$ Satjipto Raharjo. (2006). Ilmu Hukum. Bandung: Alumni, p. 45

${ }^{7}$ Ibid.

${ }^{8}$ Maria Farida. Ilmu Perundang-undangan 1. Op.Cit, p. 257
} 
a. The principle of clarity purposes

b. The institutional principles

c. The principles of conformity between the type and material of charge

d. The implementation principles

e. The principle of utility and usefulness

f. The principles of clarity of formulation

g. The principles of relevance

The content of materials in the formation of legislation must reflect the principles of :

a. The principles of guidance

b. The principles of humanity

c. The national principles

d. The principles of a family

e. The principles of the mediation

f. The principles of Bhineka Tunggal Ika

g. The principles of justice

h. The principles of equality before the law and government

i. The principles of order and legal certainty

j. The principles of balance and harmony

After considering the principles on a good legislation as well as its contains material, in the legal knowledge its known the existence of a theory or principles which always follows and start off the formation of legislation which generally became a guidance for the legislator. It is become the basic mind-set of the legislator which is as the problem solver of the legislation which have a contradiction. There are three of the important principles which existed on our national legislation : principles lexs pesialis derogate legigeneralis, principles lex superior derogate legi inferior, and principles lex posteriori legiinferiori.

Concerning the legal matters which written by the writer on the first problem statement on this research, there is norm contradiction between the basis authority of the heritage hall which listed on the circular letter of the supreme court of republic of Indonesia may 81991 and the regulation of agrarian minister number 3 year 1997 concerning the land registration with the act number 23 year 2006 concerning the citizen administration. As a legal system which united according to the hierarchy where the lower norm cannot be contradicted with the higher norms, so if the this is happen there is the application of the principle of "lexsuperiori derogate legiinferiori" which in this matter the basic authority of the heritage hall that consists of the circular letter of the supreme court and the minsters regulation which is as the lower norm compared to the act number 23 year 2006 which is a norm that placed on the higher position on the hierarchy.

According to the principles, the existence of the act number 23 year 2006 on the citizen administration it should be set aside the circular letter of supreme court and the regulation from the agrarian minister which become the basic authority of the heritage hall because its position on the hierarchy legislation lower than the act as written on the aricle 7 section 1 of law number 12 year 2011 concerning the formation of the legislation.

It is necessary to have further analysis from the perpective of the statutory science because it relation with law norms which is hierarchial where the lower norm must obtain validity from the higher norm. this is very related with the theory that stated by Hans Kelsen which is a hierarchy theory or may be called as norms stage or Stufenbau Theory 
Hans Kelsen on his theory stated that "a norms are tiered and layers on some hierarchy, where the lower norm, resourced and based from the higher norm and so on until it reach the higher norm which called (Ground-norm). This theory was developed by his student named Hans Nawiasky which stated that "the norms in a state structured in hierarchy from a general type that individual, at the top of the norm there is a ground norm (grundnormatauurprungsnormatau basic norm. $)^{9}$

By pointing at the hierarchy theory, if there is occurs conflict between the norms, such as the problem statement on this research where the authority of the heritage hall that classified the group Indonesian citizen while the government establish the law number 23 year 2006 on the citizen administration in purpose to uniform the law and rights of indonesian citizen without recognizing the classification of citizen. norm conflict like this is rights to be used a principle of "lexsuperiori derogate legiinferiori", according to this principle the basic authority of the heritage hall in the form of circular letter of supreme court and the regulation of agrarian minister where its position is lower the legislation should be set aside with the act number 23 year 2006 concerning citizen administration according to the hierarchy is in higher position. It can be concluded that if the circular letter of the Supreme court which appointed to the letter from the directorate of land registration and the regulation of agrarian minister is contradict with the government purpose in order to uniform the law and rights of Indonesian citizen as regulated under the act number 23 year 2006, the act will be first held on its position in accordance to the principle of "lexsuperiori derogate legiinferiori.

\section{The legal force of the certificate of inheritance rights that made by the heritage hall after the enactment of the act number 23 year 2006}

The authority on making an inheritance certificate is stillon the citizen classification. Other than the differences on its authority making, the form of inheritance also different there are the form of certificate and the form of deed. The heritage hall as the otority to make the inheritance certificate for the foreign east descent issued on the form of inheritance certificate. Hence, a notary making a certificate for the Chinese descent in the form of inheritance deed.

One of the legal basis of a notary on making the inheritance deed regulated under the regulation of agrarian minister number 3 year 1997. The legal basis that a notary follow on making the inheritance deed considered inappropriate. Because the basic law is a product of decision of state minister which is not a minster who holding a department, and the decision which issued by the coordinator minister and state minster is an intern decision and not bound generally, so that it cannot become a basic law on making the inheritance deed by a notary. ${ }^{10}$

If the decision is only apply internally and not be pound generally, then those decision is only applied for the intern work area of the agrarian minister and the meaning of not bound generally could be understood that the decision is does not necessary to be apply globally in the legal area in Indonesia. Then it should be the authority of a notary on making the inheritance deed more precisely refer to the article 15 of the act number 2 year 2014 concerning the amendment of the act number 30 year 2004 concerning the notary official.

The form of inheritance certificate for the Chinese descent as mention under the regulation agrarian minister for the time being was make on the from of deed of inheritance, not a certificate of inheritance. The deed is in the form of the information of the heirs which made by anotary where the minuta deed was handed by the witnesses face then keep by a notary. The minuta contains the information which delivered by the witnesses that concluded the party who has the right as a heir. Then this form can be classified as an authentic deed if seen from

\footnotetext{
${ }^{9}$ Rosjidi Ranggawidjaja. (1996). Pedoman Teknik Perancangan Peraturan Perundang-Undangan. Bandung: Cita Bhakti Akademika, p.13

${ }^{10}$ HerlienBudiono. Op.Cit.,p.98-99.
} 
the regulation of article 1868 on the civil book. According to this article, an authentic deed is a deed which made by or in front of the official who has an authority on making it in the form which determined by the law and in the area of its authority. Then the force of the inheritance deed can be said "strong" or perfect.

According to the instruction of heritage hall which listed on the stb 1916 number 517 that it is necessary to have an inheritance certificate from the heritage hall fof the foreign east group for the process of transfer of the title of the heirs. However, Herlien Budiono stated that it is not right if the civil proof issued by the authority that subject under the state administrative law ${ }^{11}$, while the certificate of inheritance ruled as a proof tool of the civil law if occurred a claim which checked by the district court. Because there are the differences on the product that issued by the official of state administration with legal product in the form of inheritance certificate as a proof tool in the civil law.

In principle, the product which issued by the official of state administration is a product in the form of written determination that contains a legal actions of administrative law which based on the applicable regulation which concrete, individual and final that may be able to raises a legal consequences for a person or civil legal entity, and for everything which causes by those product is checked in the court of state administration. ${ }^{12}$

The purpose on making the act number 23 year 2006 concerning the citizen administration is to eliminate the classification of citizen that was occurred on the colonialism. Therefore, the whole Indonesian citizen deserve the law protection and the same rights in front of the law. Then, concerning the differences on the inheritance certificate whether it is in the form of a certificate and deed are contradicted with the purpose of the regulation because the strength of a deed proof is a perfect proof while a certificate is not as perfect as a deed. The implementation of the act number 23 year 2006, then there are no more exist of Indonesian citizen which the descent from a foreign east or other descents which further the certificate that issued by the heritage hall is less guarantee the law protection.

\section{CONCLUSION}

The basic authority of the heritage hall on making the inheritance certificate for the foreign east group is no longer compatible with the condition of Indonesian citizen today. According to the legislation hierarchy theory, the position of the regulation which based on the heritage hall authority is still under the position of the act number 23 year 2006. Then, in accordance with the principle of lexsuperiori derogate legiinferiori, the authority of the heritage hall is no longer applicable.

The certificate of inheritance which made by the heritage hall is not guarantee the legal certainty of the parties yet, because the form of the certificate position on the structure of the proof tools is still under the deed so that the inheritance certificate issued by the heritage hall is not guarantee a legal certainty and legal protection for the whole Indonesian citizen. according the authority theory, in order to guarantee the legal certainty and provide protection overall, a notary is the most ideal to make the inheritance certificate for the whole Indonesian citizen which its form on a deed.

\section{BIBLIOGRAPHY}

\section{Book :}

Budi Harsono. (2005). HukumAgraria Indonesia (HimpunanPeraturanHukum Tanah).Jakarta.

\footnotetext{
${ }^{11}$ Herlien Budiono, Op.Cit, p. 95.

${ }^{12}$ Undang-undang Nomor 51 Tahun 2009 tentang Perubahan yang kedua atas Undang-undang Nomor 5 Tahun 1986 tentang Pejabat Tata Usaha Negara.
} 
Djambatan.

HabibAdjie. (2005). Stop DiskriminasiDalamPembuatanBuktiAhliWaris, Renvoi No.24. Jakarta.

HerlienBudiono, (2006). AsasKeseimbanganBagiHukumPerjanjian Indonesia. Bandung: Citra Aditya Bhakti.

Maria Farida. (2005). IlmuPerundang-undangan I. Jakarta: Kansius.

RosjidiRanggawidjaja. (1996). PedomanTeknikPerancanganPeraturanPerundang-undangan. Bandung: Citra BaktiAkademika.

SatjiptoRaharjo. (2006). IlmuHukum. Bandung: Alumni.

Soepomo.(1996). Bab-Bab TentangHukumAdat. Jakarta: PenerbitanUniversitas.

\section{Peraturan perundang-undangan:}

Undang-UndangNomor 12 Tahun 2006 tentangKewarganegaraan.Undang.

UndangNomor 23 Tahun 2006 tentangAdministrasiKependudukan.

Undang-Undang Nomor 40 Tahun 2008 tentang Penghapusan Diskriminasi Ras dan Etnis.

Undang-Undang Nomor 12 Tahun 2011 tentang Pembentukan Peraturan Perundang-Undangan.

Undang-Undang Nomor 2 Tahun 2014 tentang Perubahan Atas Undang-Undang Nomor 30 Tahun 2004 tentang Jabatan Notaris.

Peraturan Menteri Negara Agraria/Kepala Badan Pertanahan Nasional Nomor 3 Tahun 1997 tentang Ketentuan Pelaksanaan Peraturan Pemerintah Nomor 24 Tahun 1997 tentang Pendaftaran Tanah, Lembaran Negara Republik Indonesia Tahun 1997 Nomor 59, TambahanLembaran Negara Republik Indonesia Nomor 3696.

Surat Edaran oleh Badan Pembinaan Hukum Direktorat Jenderal Agraria, Departemen Dalam Negeri, tanggal 20 Desember 1969, Nomor: 44 Dp/J12/63/12/69, tentang Surat Keterangan Warisan dan Pembuktian Kewarganegaraan. 